\title{
The effects of acute cold exposure and feeding on volatile fatty acid metabolism in the hind leg of the young ox
}

\author{
By A. W. BELL, J. W. GARDNER AND G. E. THOMPSON
}

Department of Physiology, The Hannah Research Institute, AyrKA6 ${ }_{5} \mathrm{HL}$

$$
\text { (Received } 6 \text { February 1974-Accepted } 8 \text { March r974) }
$$

\footnotetext{
I. Young steers were fed either 20 or $4 \mathrm{~h}$ before exposure to a thermoneutral or a moderately cold environment. Measurements were made of total oxygen consumption (total $\dot{V}_{\mathrm{O}_{2}}$ ), respiratory quotient (RQ) and hind-leg blood flow (leg $\dot{Q}$ ) and oxygen uptake (leg $\left.\dot{V}_{\mathrm{O}_{2}}\right)$. The arteriovenous difference in plasma concentrations of individual volatile fatty acids (VFA) across the leg was also measured. Net exchange and fractional uptake of VFA by the leg were calculated from these results.

2. Cold exposure doubled total $\dot{V}_{\mathrm{O}_{2}}$, significantly decreased the RQ and caused 3 -fold and ro-fold increases in leg $\dot{Q}$ and leg $\dot{V}_{\mathrm{O}_{2}}$ respectively in both $4 \mathrm{~h}$ - and $20 \mathrm{~h}$-fed steers. Arterial plasma concentrations of total VFA (which was more than $95 \%$ acetate) and net leg uptake of VFA also significantly increased in both groups. Cold had no effect on the fractional uptake of VFA by the leg.

3. Feeding shortly before the experiment caused a significant increase in total $\dot{V}_{\mathrm{O}_{2}}$ in thermoneutrality only, and in RQ, arterial plasma VFA and net VFA uptake by the leg in both environments. There was a significant decrease in the fractional uptake of VFA by the leg.

4. Calculations suggest that although circulating acetate could, in theory, supply over $60 \%$ of the energy required by the hind leg in the resting, fed animal, less than $30 \%$ of the increased requirement of the shivering leg could be supplied by acetate during acute cold exposure, even shortly after feeding.
}

Recent studies of metabolism in the hind leg of the ox indicate that shivering skeletal muscle makes an important contribution to the metabolic response to cold of the whole animal (Bell, Thompson \& Findlay, 1974). During such shivering the circulating levels of free fatty acids (FFA) are raised in sheep (Bost \& Dorléac, 1965; Slee \& Halliday, I968) and cattle (Thompson \& Clough, 1972). That this is probably associated with increased rates of oxidation of FFA, as in cold-stressed non-ruminants (Paul \& Holmes, I973) is indicated by the decrease in respiratory quotient (RQ) reported for sheep (Graham, Wainman, Blaxter \& Armstrong, 1959) and steers (Blaxter \& Wainman, I96r) exposed to cold environments.

Short-chain steam-volatile fatty acids (VFA) are the major source of energy of the normally-fed ruminant (Blaxter, I967; Annison \& Armstrong, I 970). However, little is known about peripheral VFA utilization during acute cold exposure when metabolic requirements are suddenly increased. Therefore in the present experiments the net exchange of individual VFA across the hind leg was measured simultaneously with leg oxygen uptake (leg $\dot{V}_{\mathrm{O}_{2}}$ ) in young steers exposed to thermoneutral and cold environments. The effect of feeding shortly before experiments were conducted was also measured. 
Table I. Effects of cold and feeding on total oxygen consumption (total $\dot{V}_{\mathrm{O}_{2}}$ ), respiratory quotient $(\mathrm{RQ})$, leg blood flow (leg $\dot{\mathrm{Q}}$ ) and leg oxygen uptake $\left(\right.$ leg $\left.\dot{V}_{\mathrm{O}_{2}}\right)$ in steers

\begin{tabular}{|c|c|c|c|c|c|c|c|c|}
\hline \multirow{3}{*}{$\begin{array}{l}\text { Treatment } \\
\text { Thermoneutral } \\
20 \text { h-fed } \\
4 \text { h-fed }\end{array}$} & \multicolumn{2}{|c|}{$\begin{array}{c}\text { Total } \dot{V}_{\mathrm{O}_{2}} \\
(\mathrm{ml} / \mathrm{kg} \text { per min) }\end{array}$} & \multicolumn{2}{|c|}{$\mathbf{R Q}$} & \multicolumn{2}{|c|}{$\begin{array}{c}\operatorname{Leg} \dot{Q} \\
(\mathrm{ml} / \mathrm{min})\end{array}$} & \multicolumn{2}{|c|}{$\begin{array}{l}\operatorname{Leg} \dot{V}_{\mathrm{O}_{2}} \\
(\mathrm{ml} / \mathrm{min})\end{array}$} \\
\hline & Mean & $\mathrm{SE}$ & Mean & $\mathrm{SE}$ & Mean & $\mathrm{SE}$ & Mean & $\mathrm{SE}$ \\
\hline & $\begin{array}{l}5 \cdot 78 \\
6 \cdot 64\end{array}$ & $\begin{array}{l}0.13 \\
0.14\end{array}$ & $\begin{array}{l}0.92 \\
1 \cdot 04\end{array}$ & $\begin{array}{l}0.02 \\
0.03\end{array}$ & $\begin{array}{l}4 \text { II } \\
43^{1}\end{array}$ & $\begin{array}{r}5 \\
46\end{array}$ & $\begin{array}{l}8 \cdot 96 \\
8 \cdot 44\end{array}$ & $\begin{array}{l}0.59 \\
2.19\end{array}$ \\
\hline \multicolumn{9}{|l|}{ Cold } \\
\hline $\begin{array}{r}20 \text { h-fed } \\
4 \text { h-fed }\end{array}$ & $\begin{array}{l}10 \cdot 16 \\
10 \cdot 39\end{array}$ & $\begin{array}{l}0.31 \\
0.77\end{array}$ & $\begin{array}{l}0.82 \\
0.88\end{array}$ & $\begin{array}{l}0.05 \\
0.02\end{array}$ & $\begin{array}{l}1304 \\
123^{\circ}\end{array}$ & $\begin{array}{l}129 \\
129\end{array}$ & $\begin{array}{l}85 \cdot 7 \\
81 \cdot 5\end{array}$ & $\begin{array}{l}9 \cdot 3 \\
8 \cdot 4\end{array}$ \\
\hline \multicolumn{9}{|c|}{ Significance of effects: } \\
\hline $\begin{array}{l}\text { Feeding (F) } \\
\text { Ev. F }\end{array}$ & & & & & & & & \\
\hline
\end{tabular}

NS, not significant; *** $P<0.001$; ** $P<0.01$; * $P<0.05$.

\section{EXPERIMENTAL}

Animals and diets. Six Ayrshire steers aged 6-8 months and weighing 82-1 $32 \mathrm{~kg}$ were used. They were housed in a heated byre in which ambient temperatures ranged from $9^{\circ}$ to $I 5^{\circ}$ and were individually fed $1 \cdot 5^{-2} \mathrm{~kg}$ of a mixture of chopped straw, rolled barley, cattle pellets and molasses twice daily.

Animal preparation. Each steer had its right common carotid artery chronically placed in a loop of skin at least I month before experiments began. Permanent indwelling cannulas were placed in the external iliac artery and vein of one hind leg as described previously (Bell et al. I974). Before its first experiment each animal was acclimatized to experimental procedures and surroundings and was clipped over the hind-quarters to increase the rate of cooling during cold exposure.

Experimental design and procedure. These experiments were done conjointly with a study of the effects of cold on several cardiovascular measurements (Bell \& Thompson, I974). In each experiment an animal was exposed to either a thermoneutral or a cold environment and was last fed either 4 or $20 \mathrm{~h}$ before the experiment started. Water was freely available to all steers until about $3 \mathrm{~h}$ before an experiment. The four possible combinations of environmental and feeding treatments were replicated three times and each animal was randomly allocated to two experiments. No animal underwent the same treatment combination twice.

The exteriorized carotid artery was cannulated immediately after feeding time on the morning of experiment. The animal was then placed in a climatic room at $14^{\circ}-16^{\circ}$ with still air (thermoneutral) or at $2.5^{\circ}-4.5^{\circ}$ with a wind of $120 \mathrm{~m} / \mathrm{min}$ blowing on the lightly wetted hind-quarters (moderately cold). Measurement of whole animal oxygen consumption (total $\dot{V}_{\mathrm{O}_{2}}$ ) began immediately. Other measurements did not begin until total $\dot{V}_{\mathrm{O}_{2}}$ was steady, and during cold exposure at a level about twice that of the resting $20 \mathrm{~h}$-fed steer. This usually took at least $\mathrm{I} h$. Duplicate series of experimental measurements were then made, each lasting I 5-20 min, with about I h separating the start of each series.

Measurements. Total $\dot{V}_{\mathrm{O}_{2}}$ and $\mathrm{RQ}$ were measured with an open circuit apparatus. 
Hind-leg blood flow (leg $\dot{Q}$ ) was measured by a dye dilution method and hind-leg oxygen consumption (leg $\dot{V}_{\mathrm{O}_{2}}$ ) by application of the Fick principle after measuring the arteriovenous difference across the leg (arterial-external iliac venous, A-EIV) in blood oxygen saturation and haemoglobin concentration by spectrophotometric methods. Details of these methods have been described by Bell et al. (1974).

The measurement of leg $\dot{Q}$ involves simultaneous sampling of carotid arterial and external iliac venous blood. Plasma concentrations of VFA in aliquots of these samples were estimated after extraction of VFA as their sodium salts into propan-2-ol containing a known amount of $n$-hexanoic acid as internal standard. After concentration the acids were individually determined by gas-liquid chromatography in diethyl ether-formic acid (9:I, v/v). This method has been described by Gardner \& Thompson (1974).

Leg plasma $\dot{Q}$, net exchange of VFA across the leg and fractional uptake of VFA by the leg were calculated from measured values by the following equations:

$$
\text { Leg plasma } \dot{Q}=\operatorname{leg} \dot{Q} \times \frac{\text { I00-packed cell volume }}{\text { IO0 }}
$$

Net exchange of VFA = leg plasma $\dot{Q} \times($ A-EIV $)$ VFA concentration,

Fractional uptake of VFA $=\frac{\text { (A-EIV) VFA concentration }}{\text { Arterial VFA concentation }}$.

Statistics. The standard error of each treatment mean was estimated, and the significance of the effects of environment and short-term feeding, and of any interaction between them, was tested using the estimated standard errors of these effects.

\section{RESULTS \\ Effects of cold}

The intended doubling of total $\dot{V}_{\mathrm{O}_{2}}$ during cold exposure was accompanied by 3 -fold and Io-fold increases in leg $\dot{\mathrm{Q}}$ and leg $\dot{V}_{\mathrm{O}_{2}}$ respectively, while RQ decreased significantly $(P<0.0 \mathrm{I})$ in both $20 \mathrm{~h}$ - and 4 -h-fed animals (Table $\mathrm{r}$ ).

Arterial levels of acetate and total VFA increased about $50 \%(P<0.01)$ in both feeding groups in response to cold (Table 2 ). In all plasma samples, acetate contributed more than $95 \%$ of the total VFA, regardless of environmental or feeding treatment. However, in spite of its low concentration, there was also a detectable increase $(P<0.05)$ in arterial propionate in the $4 \mathrm{~h}$-fed groups only.

Since arterial - venous $(\mathrm{A}-\mathrm{V})$ difference in plasma VFA across the leg tended to vary with arterial level, cold exposure had no significant effect on fractional uptake $((\mathrm{A}-\mathrm{V}) \div \mathrm{A})$ of acetate or total VFA by the leg (Table 2$)$. However, this relationship between arterial level and $\mathrm{A}-\mathrm{V}$ difference was not strong enough to show a significant response to cold. Thus the highly significant increase in leg uptake of acetate and total VFA $(P<0.00 \mathrm{I})$, and the significant increases in uptake of propionate $(P<0.01)$ and butyrate $(P<0.05)$ ('Table 2$)$ largely reflected substantial increases in leg $\dot{Q}$. 


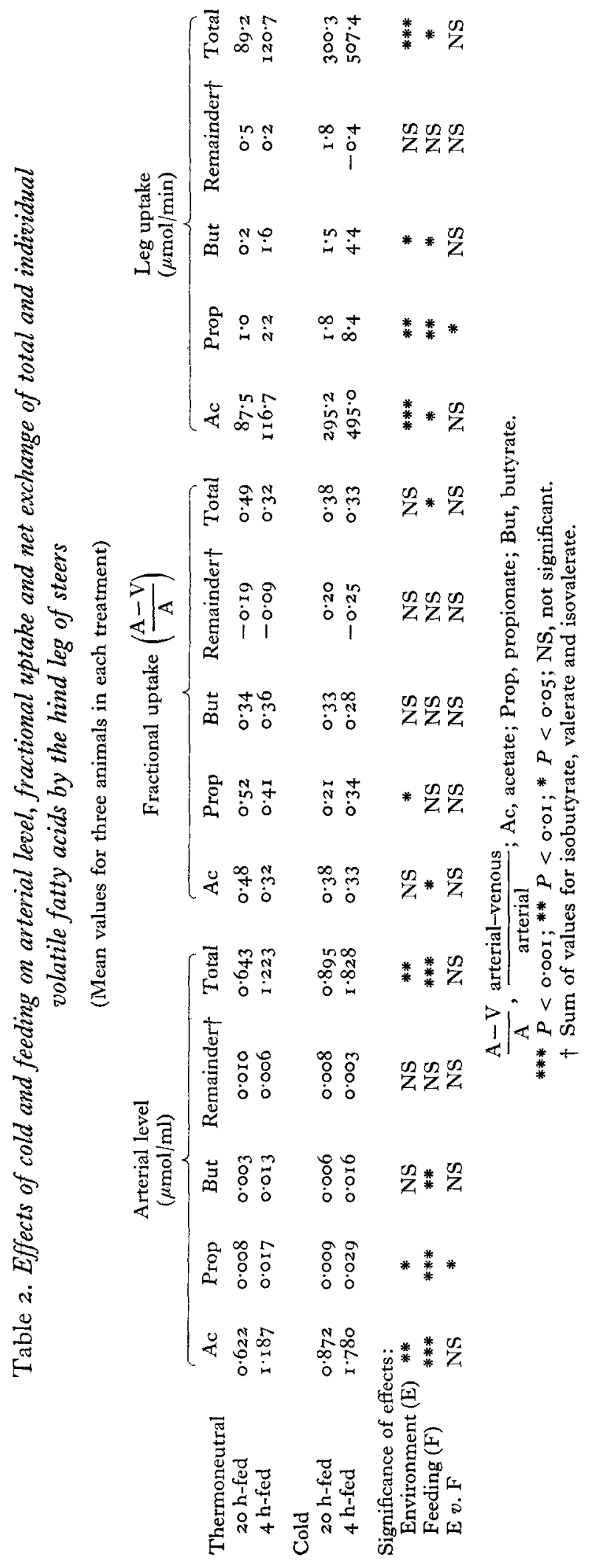


Table 3. Effects of cold and feeding on the possible contribution of acetate oxidation to the metabolism of the hind leg of steers

\begin{tabular}{|c|c|c|c|}
\hline Treatment & $\begin{array}{c}\text { Leg oxygen uptake } \\
\left(\text { leg } \dot{V}_{\mathrm{O}_{2}}\right) \\
(\mathrm{mmol} / \mathrm{min})\end{array}$ & $\begin{array}{l}\text { Leg uptake of acetate } \\
(\mathrm{mmol} / \mathrm{min})\end{array}$ & $\frac{\text { Acetate uptake }}{\dot{V}_{\mathrm{O}_{2}}} \times 100$ \\
\hline \multicolumn{4}{|c|}{ Thermoneutral } \\
\hline $20 \mathrm{~h}$-fed & 0.40 & 0.09 & 45 \\
\hline 4 h-fed & 0.38 & 0.12 & 63 \\
\hline \multicolumn{4}{|l|}{ Cold } \\
\hline $20 \mathrm{~h}$-fed & $3 \cdot 82$ & 0.30 & 16 \\
\hline $4 \mathrm{~h}$-fed & 3.64 & $0.5 \mathrm{I}$ & 28 \\
\hline
\end{tabular}

\section{Effects of feeding}

The analysis of over-all treatment means did not reveal any significant feeding effects on the measurements shown in Table $\mathrm{I}$, except for RQ, which was higher in the $4 \mathrm{~h}$-fed steers in both environments $(P<0.05)$. However, comparison of mean values for the $20 \mathrm{~h}$ - and $4 \mathrm{~h}$-fed groups in each environment showed that total $\dot{V}_{\mathrm{O}_{2}}$ was significantly increased $(P<0.0 \mathrm{I})$ by feeding shortly before the experiment in the thermoneutral environment only.

Arterial levels of individual and total VFA were approximately doubled by feeding in both environments (Table 2). Although fractional uptake of acetate and total VFA was lower in the 4 h-fed group $(P<0.05)$, the $\mathrm{A}-\mathrm{V}$ differences in concentrations of these acids were sufficiently greater in this group to ensure significant increases in leg uptake of acetate $(P<0.05)$ and total VFA $(P<0.05)$ due to feeding. There were also significant increases in leg uptake of propionate $(P<0.01)$ and butyrate $(P<0.05)$.

\section{DISCUSSION}

Validation tests of the method used to estimate peripheral plasma VFA concentrations in this study have been reported elsewhere (Gardner \& Thompson, I974). Plasma acetate levels in the fed and $20 \mathrm{~h}$-fasted steers werc within the range of values reported for the whole blood of fed and 24 h-fasted sheep (Lindsay \& Ford, I964; Annison, Brown, Leng, Lindsay \& West, 1967) and cattle (Davis, Brown, Staubus \& Nelson, 1960; Lee \& Williams, 1962). The very low arterial plasma levels of propionate, butyrate and other acids were similar to those of fed shecp (Ross \& Kitts, r973). The remainder of the discussion will be limited to acetate, which is the only VFA in peripheral plasma of quantitative importance as an energy substrate.

The significant increase in arterial acetate levels in both $4 \mathrm{~h}$-fed and $20 \mathrm{~h}$-fed animals during cold exposure was most likely to have been duc to enhanced rates of production of endogenous acetate. A variety of different methods have been used to demonstrate that in the fed shcep, in a presumably thermoneutral environment, about $40-50 \%$ of total acetate turnover is produced endogenously (Annison \& White, I 962; Annison \& Armstrong, 1970; Bergman \& Wolff, 197I). There is evidence that $\beta$ oxidation of long-chain fatty acids can contribute to this endogenous production of acetate, particularly when plasma FFA levels are raised, as in fasting (West \& Annison, 
1964; Palmquist, 1972). Thus it is likely that the increased levels of FFA reported for cold-stressed cattle (Thompson \& Clough, 1972) are related to an increased rate of endogenous acetate production.

Such an increase in the output of acetate from tissues of the leg would tend to mask the degree of extraction of this metabolite by the leg. This is borne out by the lack of a significant difference between $\mathrm{A}-\mathrm{V}$ differences in acetate across the leg measured during thermoneutral and cold conditions. Thus the marked increase in the net uptake of acetate by the leg during cold exposure was due almost entirely to the great increase in leg $Q$ which has been demonstrated previously in the ox (Bell et al. 1974).

It is likely that most acetate utilization in the leg occurs in skeletal muscle, which despite having low acetate thiokinase activity (Ballard, I972) accounts for a significant proportion of acetate uptake in the intact sheep (Holdsworth, Neville, Nader, Jarrett \& Filsell, 1964) and has been shown to metabolize acetate in vitro (Mayfield, Bensadoun \& Johnson, r966). The leg also contains small depots of adipose tissue which can utilize acetate for triglyceride synthesis or oxidation to $\mathrm{CO}_{2}$ (Ballard, Filsell \& Jarrett, I972).

When leg uptake of oxygen and acetate are expressed in $\mathrm{mmol} / \mathrm{min}$ (Table 3 ) it is evident that, if oxidized to completion, acetate could account for about $60 \%$ of the metabolic requirement of the leg of a resting, fed steer. This contrasts with an estimate of $36 \%$ for the hind-limb of the fed sheep (Ballard, I972). However, the A-V oxygen difference across the leg in the latter study indicates a degree of oxygen uptake greater than that of the truly resting animal. In the present experiments short-term fasting, as might be expected, reduced the possible contribution of acetate to leg metabolism and this was reduced further still by cold exposure, when leg $\dot{V}_{\mathrm{O}_{2}}$ increased 1o-fold.

It is thus evident that, even in steers fed shortly before acute cold exposure, circulating VFA, and acetate in particular, are unable to meet the sudden increase in the requirement for energy substrate. It is likely that these demands are met by the rapid mobilization of FFA seen in cattle under these conditions (Thompson \& Clough, 1972). Increased FFA oxidation in the cold was indicated by the significant decrease in RQ of both fed and fasted animals in the present study, and the increased turnover rate of FFA in cold-exposed cattle (A. R. Marshall, personal communication) was presumably associated with an increased oxidation rate as in other species during cold exposure (Paul \& Holmes, r973).

The authors are grateful to Mrs J. Hunter for surgical assistance, and to Misses J. Veitch and E. Waugh for technical assistance.

\section{REFEREN CES}

Annison, E. F. \& Armstrong, D. G. (1970). In Physiology of Digestion and Metabolism in the Ruminant p. 422 [A. T. Phillipson, editor]. Newcastle upon Tyne: Oriel Press.

Annison, E. F., Brown, R. E., Leng, R. A., Lindsay, D. B. \& West, C. E. (I967). Biochem. F. ro4, I35.

Annison, E. F. \& White, R. R. (1962). Biochem. F. 84, 546.

Ballard, F. J. (1972). Am. F. clin. Nutr. 25, 773 .

Ballard, F. J., Filsell, O. H. \& Jarrett, I. G. (1972). Biochem. F. 126, 193.

Bell, A. W. \& Thompson, G. E. (1974). Res. vet. Sci. (In the Press.) 
Bell, A. W., Thompson, G. E. \& Findlay, J. D. (1974). Pflügers Arch. ges. Physiol. 346, 341.

Bergman, E. N. \& Wolff, J. E. (1971). Am. 7. Physiol. 221, 586.

Blaxter, K. L. (1967). The Energy Metabolism of Ruminants, 2nd ed. London: Hutchinson Scientific and Technical.

Blaxter, K. L. \& Wainman, F. W. (I96r). F. agric. Sci., Camb. 56, 81.

Bost, J. \& Dorléac, E. (1965). C. $r$. Séanc. Soc. Biol. 159, 2209.

Davis, C. L., Brown, R. E., Staubus, J. R. \& Nelson, W. O. (1960). F. Dairy Sci. 43, 23 I.

Gardner, J. W. \& Thompson, G. E. (r974). Analyst, Lond. 99, 326.

Graham, N. McC., Wainman, F. W., Blaxter, K. L. \& Armstrong, D. G. (1959). F. agric. Sci., Camb. 52,13 .

Holdsworth, E. S., Neville, E., Nader, C., Jarrett, I. G. \& Filsell, O. H. (1964). Biochim. biophys. Acta 86, 240.

Lee, S. D. \& Williams, W. F. (1962). F. Dairy Sci. 45, 893.

Lindsay, D. B. \& Ford, E. J. H. (I964) Biochem. J. 90, 24.

Mayfield, E. D., Bensadoun, A. \& Johnson, B. C. (1966). F. Nutr. 89, I 89.

Palmquist, D. L. (1972). F. Nutr. 102, 1401.

Paul, P. \& Holmes, W. L. (1973). Lipids 8, 1.42.

Ross, J. P. \& Kitts, W. D. (1973). F. Nutr. 103, 488.

Slee, J. \& Halliday, R. (1968). Anim. Prod. ro, 67.

Thompson, G. E. \& Clough, D. P. (1 972). Q. Yl exp. Physiol. 57, 192.

West, C. E. \& Annison, E. F. (1964). Biochem. F. 92, 573. 